\title{
Lake Kivu Water Chemistry Variation with Depth Over Time, Northwestern Rwanda
}

\author{
F. Hategekimana,", J.D.Ndikuryayo, E.Habimana, T. Mugerwa, Kakonkwe Christian and \\ Rwabuhungu R. Digne Ed. \\ Department of Geology, School of Mining and Geology, University of Rwanda \\ *Telephone number: +250789927098 \\ *Corresponding author: francoishate@gmail.com
}

\begin{abstract}
The water of East African_rift lakes contains large amounts of dissolved chemicals such as carbon dioxide, methane greatly and others like phosphate, silicate, Sulfate, Sulfide, Iron, Ammonia, Alkalinity etc. Lake Kivu is a large, deep rift basin lake located in the western branch of the East African rift zone that contains a methane gas deposit of great economic interest with two main sources: Inorganic carbon dioxide $\mathrm{CO}_{2}+4 \mathrm{H}_{2}=\mathrm{CH}_{4}+2 \mathrm{H}_{2} \mathrm{O}$ and Organic methanogenesis $\mathrm{CH}_{3} \mathrm{COOH}=\mathrm{CH}_{4}+\mathrm{CO}_{2}$. Lake Kivu is a stratified, meromictic lake bordering Rwanda and the Democratic Republic of the Congo (DRC). The lake has a surface area of 2,370 $\mathrm{Km}^{2}$, a volume of $580 \mathrm{Km}^{3}$ and a maximum water depth of $485 \mathrm{~m}$. To characterize the vertical variation of Lake Kivu water chemistry, 8 samples of water were collected using Niskin bottles in Lake Kivu near Gisenyi town. Water samples were therefore collected at different depths: 0 m, 40 m, 90 m, 240 m, 290 m, $340 \mathrm{~m}, 340 \mathrm{~m}$, and $390 \mathrm{~m}$. Hatch kits were used to analyze water chemistry of samples taken of Sulfate, Sulfide, Iron, Ammonia, Alkalinity, Silica, $\mathrm{PO}_{4}$,andphosphorus. The results revealed that alkalinity increases in the monimolimnion part due to the precipitation of calcium carbonate in the upper levels of the water column and dissolution in the monimolimnion. The conductivity, dissolved oxygen, temperature and $\mathrm{pH}$ weremeasured by CTD Sonde. Water column data from these studies showed increasing concentrations with depth. The divide between the mixolimnion and monomolimnion is estimated at a depth of around $40 \mathrm{~m}$. Higher amounts of silica observed closer to the shoreline is likely a result of an
\end{abstract}


influx of siliciclastic sediment and increased silica with depth is likely a result of the dissolution of diatoms below the photic zone.

Keywords: Monimolimnion, mixolimnion, water stratification, chemicals agents.

\section{Introduction}

Lake Kivu is an East African rift lake having a maximum depth of $485 \mathrm{~m}$, a volume of $550 \mathrm{~km}^{3}$, elevation of $1463 \mathrm{~m}$, and it has an area of $2370 \mathrm{~km}^{2}$. Lake Kivu is located between the Democratic Republic of Congo and Rwanda(Schmid et al., 2004).The water of East Africanrift lakes contains large amounts of dissolved gases such as carbon dioxide and methane especially in Kivu Lake which is located in Rwanda. Lake Kivu is one of the largest carbon dioxide and methane reservoirs on earth (source). In 2004, the calculated amount of $\mathrm{CO}_{2}$ and $\mathrm{CH}_{4}$ dissolved phase is $300 \mathrm{~km}^{3}$ and $55 \mathrm{~km}^{3}$ at standard temperature and pressure (gas volume at 0 degree celcius and $1 \mathrm{~atm}$ (Schmid et al. 2005). According to Selley(1998), Methane is formed in three ways: 1) mantle-derived, 2) thermal maturation of organic matter and 3) bacterial degradation of organic matter at the shallow depths. In the case of methane in Lake Kivu water column, the dominant methane-forming process is bacteria-mediated methanogenesis of $\mathrm{CO} 2$. Carbon dioxide is the major natural gas in the areas of extensive volcanic activity. There are other gases, ions, and anionsthat are present in smaller quantities like silica, phosphate, iron, sulfide, ammonia etc. (Degens et al. 1973).The chemistry of water changes with depth from top. For example, $\mathrm{Fe}$ concentration below mixolimnion is higher because of anoxia(Schmid et al. 2005).This resesrch intend to study Lake Kivu's water chemistry changes over time versus spatially at depth and the temporal variability as a result of of photosynthesis occurring during the day. This study aimed at studying the variations in dissolved oxygen, alkalinity, $\mathrm{pH}$, conductivity, silica, phosphate, iron, sulfide, sulfate, and ammonia in Lake Kivu water over time from the surface to the bottom and how water chemistry between mixolimnion and monimolinion differs. Data in this study were acquired using Hach kits that are suitable for studying water chemistry of Lake Kivu due to the fact that it is quick, simple, easy to transport, and fast with few field assistance Contrarily, it has low detection limit for phosphate and ammonia and Likely less precise than IC/ICP (Ion Chromatography/Inductively Coupled Plasma). 
This study will help to identify the influence of surrounding environment on the chemistry of Lake Kivu water and asses the impacts of chemicals on aquatic life. The divide between the mixolimnion and monomolimnion occurs at a depth of around $\sim 65 \mathrm{~m}$ (Schmid\&Wüest, 2012). The lake is anoxic below 60-65 meter deep. Lake Kivu has large gas reservoir at the depth between 50 and $80 \mathrm{~m}$ (Schimitz\&Kufferah, 1955;Capart,1960), this is of economic importance but also risky. Lake Kivu waters are drained by different fluid sources and/or biochemical processes controlling water chemistry (i.e., water-rock interactions, bacterial activity) that is not homogeneously distributed all over the entire lake (Tasi et al, 2009).

\section{Methods}

Eight water samples were collected at depths extending from the surface to the depth of 390 meters and at interval depth of $(0 \mathrm{~m}, 40 \mathrm{~m}, 90 \mathrm{~m}, 240 \mathrm{~m}, 290 \mathrm{~m}, 340 \mathrm{~m}, 340 \mathrm{~m}, 390 \mathrm{~m})$ using

Niskin bottles suspended on the calibrated cord in Lake Kivu near Gisenyi city with help of Kilindi boat. Conductivity, Temperature and Depth (CTD)Sonde data were also collected along the depth profile. Water samples were analyzed in the Lake Kivu Monitoring Program laboratory using Hatch kits. The measured elemental concentrations are ofSulfate, Sulfide, Iron, Ammonia, Alkalinity, Silica, and Phosphate as the major chemical constituents of Lake Kivu water.

\section{Silica measurement}

The method used is Silico-molybdate Method (SILICA, High Range (0 to $75.0 \mathrm{mg} / \mathrm{L}$ )).Samples were collected in clean plastic bottles. The samples were analyzed just after collection and stored up to 28 days at $4{ }^{\circ} \mathrm{C}$ or below. The analysis was preceded by warming the samples to room temperature before analyzing. Silica and Phosphate in the sample reacted with molybdate ion under acidic conditions to form yellow silicomolybdic acid complexes and phospho-molybdic acid complexes. Citric acid was added to destroy the phosphate complexes. Silica is then determined by measuring the remaining yellow color.

\section{Alkalinity}

Samples were collected in a clean glass or plastic bottles with tight-fitting caps. The bottlewas completely filled with water and immediately tighten the cap to prevent agitation of the sample 
and air exposure. Then, Analyzed the samples as soon as possible for best results. The alkalinity was measured by using digital titrator for Phenolphthalein and Total Alkalinity from 10 to 4000 $\mathrm{mg} / \mathrm{L}$ as $\mathrm{CaCO}_{3}$.

\section{Sulfide}

Samples of water were collected in clean plastic or glass bottles and filled completely and cap tightly to avoid excessive agitation or prolonged exposure to air and analyzed samples immediately. The analysis used Methylene Blue Method for SULFIDE (0 to $0.70 \mathrm{mg} / \mathrm{L} \mathrm{S2-}$ ).

\section{Phosphate.}

Water samples were collected in plastic or glass bottles that have been cleaned with 1:1 Hydrochloric Acid Solution and rinsed with deionized water. PhosVer 3 (Ascorbic Acid) Method for PHOSPHORUS, REACTIVE (0 to $2.50 \mathrm{mg} / \mathrm{L}$ PO43-) was used.

\section{Iron}

Samples of water were collected in plastic containers. No acid addition is necessary if analyzing the sample immediately. To preserve samples, the $\mathrm{pH}$ was adjusted to 2 or less with nitric acid (about $2 \mathrm{~mL}$ per liter). The method used is FerroVer Method forIRON (0 to $3.00 \mathrm{mg} / \mathrm{L}$ ) .

\section{Sulfate}

Water samples were collected in clean plastic bottles and warm to room temperature before analysis. The analysis was done using SulfaVer 4 Method for SULFATE (0 to $70 \mathrm{mg} / \mathrm{L}$ ). 


\section{Results}

Table 1.The change of concentrations o different chemicals with depth.

\begin{tabular}{|c|c|c|c|c|c|c|c|c|c|c|c|}
\hline $\begin{array}{l}\text { Sample } \\
\text { number }\end{array}$ & $\begin{array}{l}\text { Depth } \\
\text { (m) }\end{array}$ & $\begin{array}{l}\text { Sulfide } \\
(\mathrm{mg} / \mathrm{l})\end{array}$ & $\begin{array}{l}\text { Ammonia } \\
(\mathrm{mg} / \mathrm{l})\end{array}$ & $\begin{array}{l}\text { Sulfate } \\
(\mathrm{mg} / \mathrm{l})\end{array}$ & $\begin{array}{l}\text { Phosphorus } \\
(\mathrm{mg} / \mathrm{l})\end{array}$ & $\begin{array}{l}\text { Silica } \\
(\mathrm{mg} / \mathrm{l})\end{array}$ & $\begin{array}{l}\text { Iron } \\
(\mathrm{mg} / \mathrm{l})\end{array}$ & $\begin{array}{l}\text { Alkalinity } \\
(\mathrm{eq} / \mathrm{l})\end{array}$ & $\mathrm{pH}$ & $\begin{array}{l}\text { DO } \\
(\mathrm{mg} / \mathrm{l})\end{array}$ & $\begin{array}{l}\text { Cond } \\
\mathrm{mSv}\end{array}$ \\
\hline \multirow[t]{2}{*}{1} & 0 & 0 & 0 & 8 & 0.13 & 9.2 & 0.09 & 11.76 & 9,9 & 10.26 & 1.126 \\
\hline & & & & & & & & & 1 & & \\
\hline \multirow[t]{2}{*}{2} & 40 & 0 & 0 & 9 & 0.13 & 8.5 & 0.08 & 11.74 & 9.5 & 10.95 & 1.173 \\
\hline & & & & & & & & & 5 & & \\
\hline \multirow[t]{2}{*}{3} & 90 & 0.8 & 0.6 & 0 & 1.68 & 21.8 & 0.03 & 20 & 7.2 & 6.02 & 2.056 \\
\hline & & & & & & & & & 4 & & \\
\hline \multirow[t]{2}{*}{4} & 240 & 0.09 & 0.6 & 0 & 2.50 & 46.1 & 0.05 & 40.8 & 6.6 & 4.6 & 3.348 \\
\hline & & & & & & & & & 8 & & \\
\hline \multirow[t]{2}{*}{5} & 290 & 0.21 & 0.46 & 1 & 2.50 & 62.9 & 0.12 & 62.8 & 6.3 & 4.85 & 4.95 \\
\hline & & & & & & & & & 5 & & \\
\hline \multirow[t]{2}{*}{6} & 340 & 0.11 & 0.6 & 1 & 2.50 & 46.7 & 0.08 & 52 & 6.2 & 4.88 & 5.59 \\
\hline & & & & & & & & & 4 & & \\
\hline \multirow[t]{2}{*}{7} & 340 & 0.14 & 0.44 & 1 & 2.50 & 65.1 & 0.12 & 75.2 & 6.2 & 4.88 & 5.88 \\
\hline & & & & & & & & & 4 & & \\
\hline \multirow[t]{2}{*}{8} & 390 & 0.18 & 0.6 & 1 & 2.50 & 60.5 & 0.11 & 62.4 & 6.2 & 4.35 & 5.74 \\
\hline & & & & & & & & & 2 & & \\
\hline
\end{tabular}

The biological degradation of organic matter in shallow depths uses oxygen. In anaerobic condition, nitrate and sulfate are used by bacteria in organic matter degradation producing carbon dioxide, methane and hydrogen sulfide. The hydrogen sulfide precipitates with iron and removed from the lake, and diffuses upward where it oxides back to sulphate. 


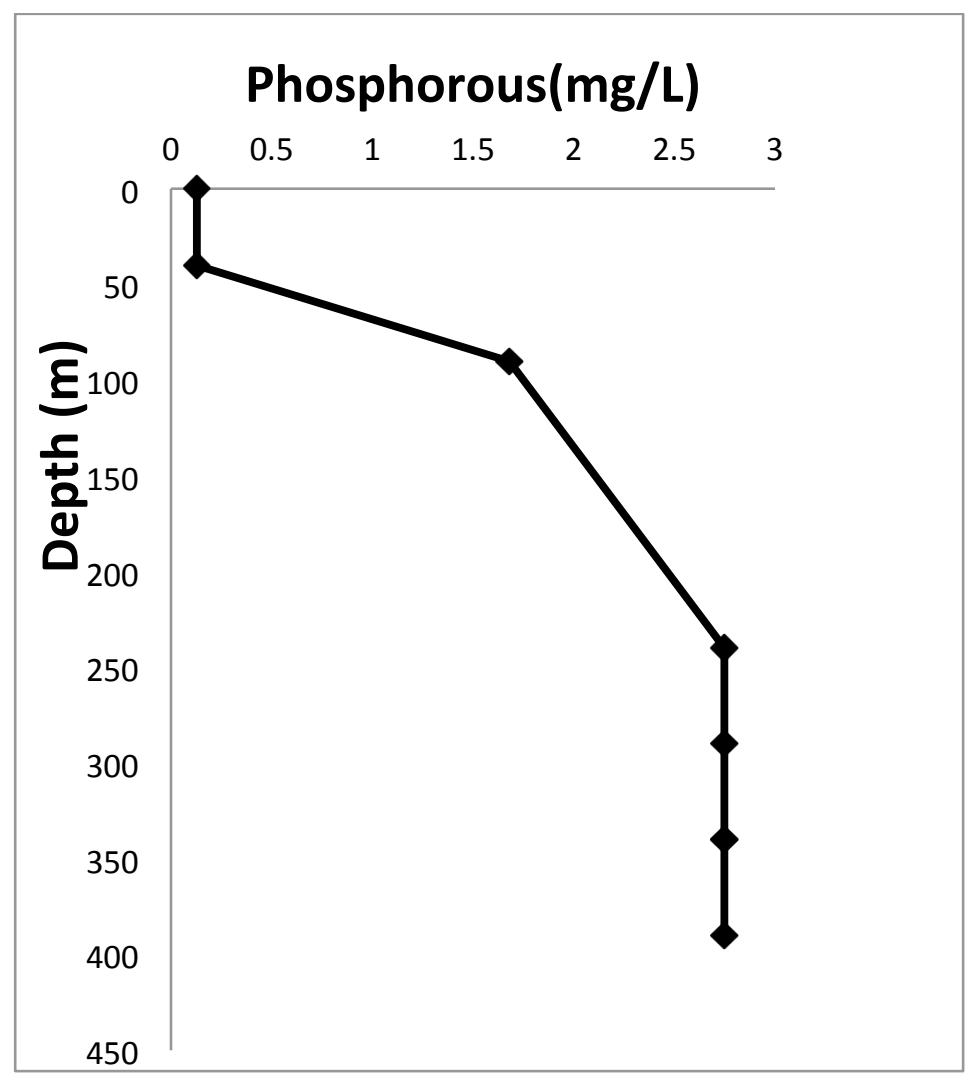

Figure 1. The concentration of phosphorus with depth.

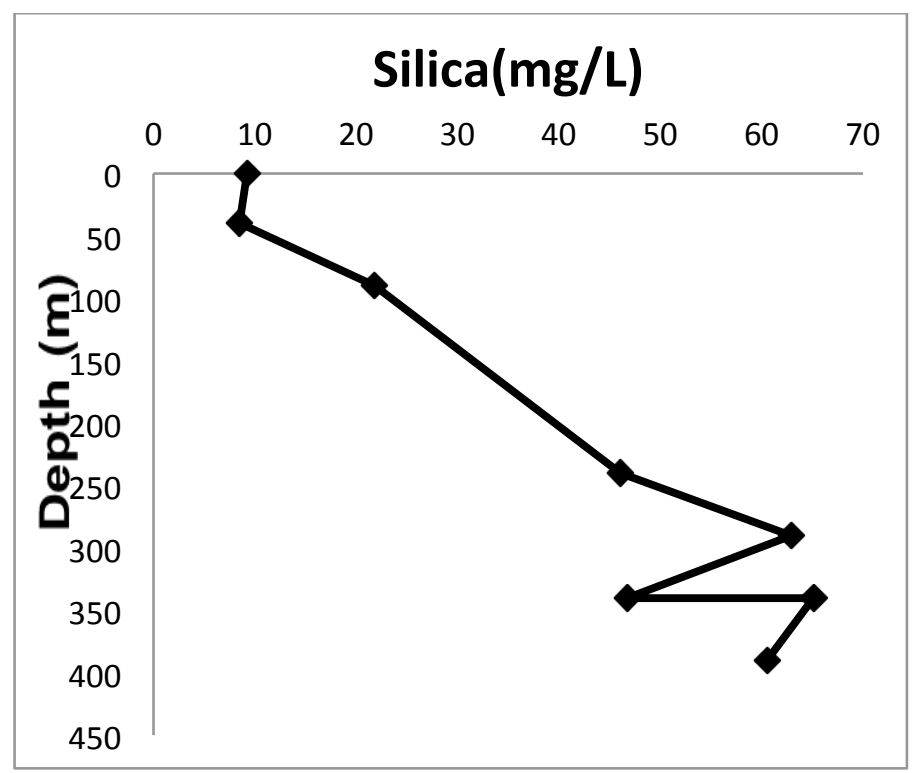

Figure 2. The concentration silica with depth 


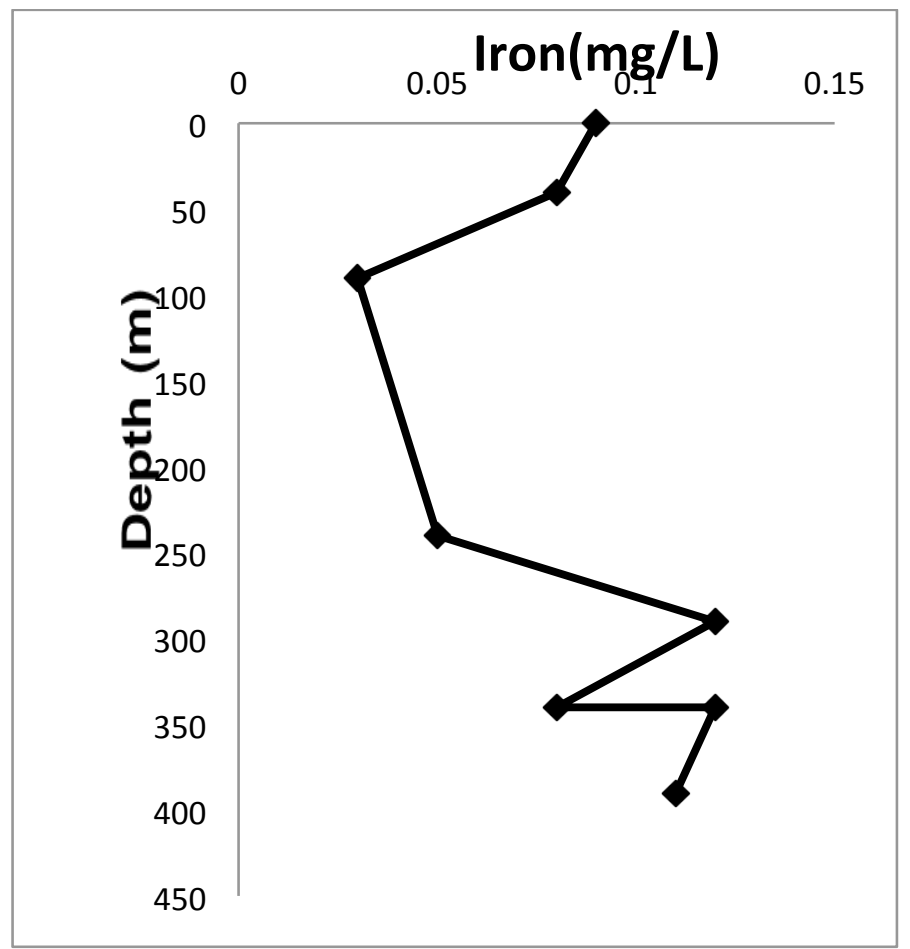

Figure 3. The concentration of iron with depth

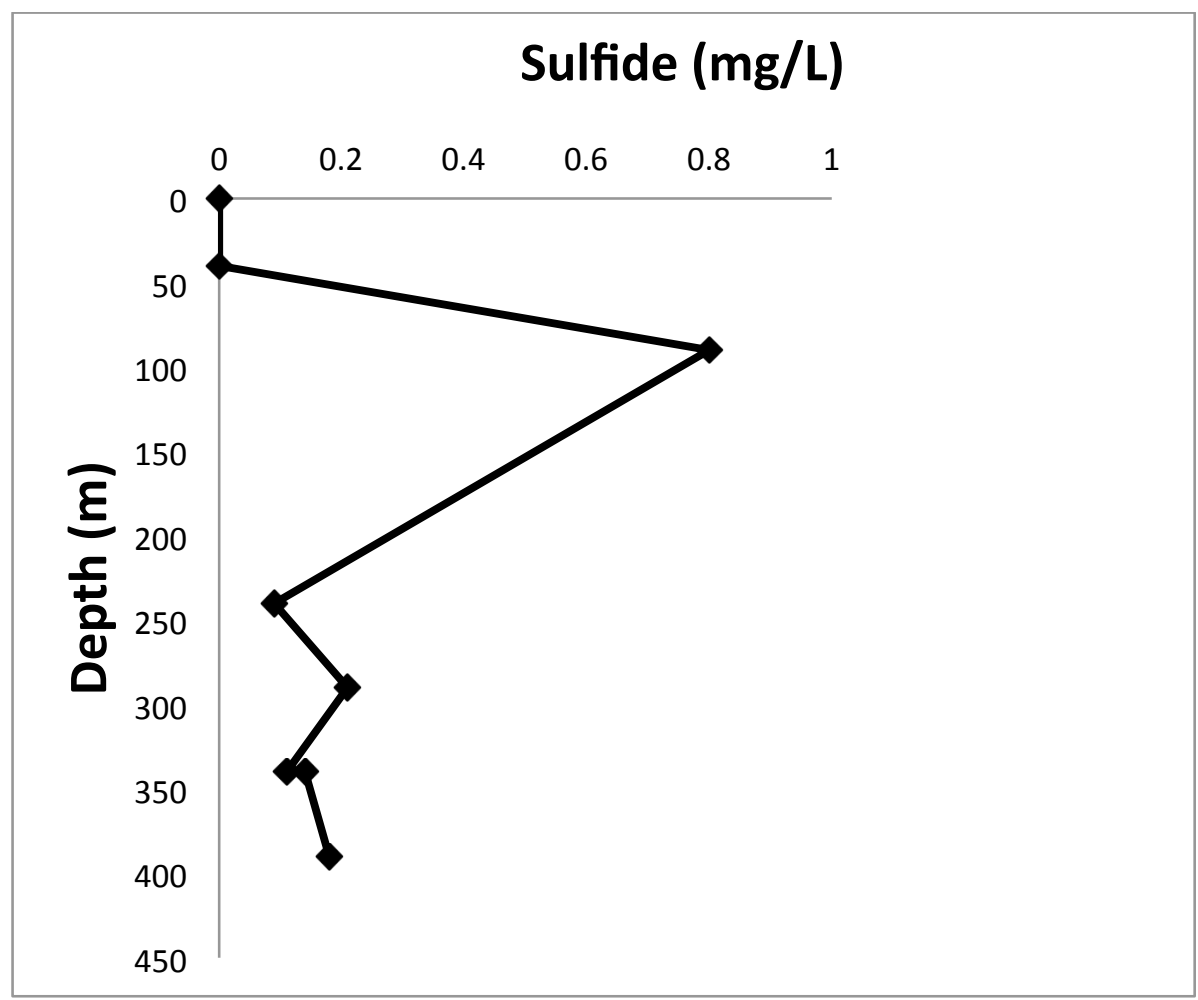

Figure 4. The concentration of sulfide with depth 


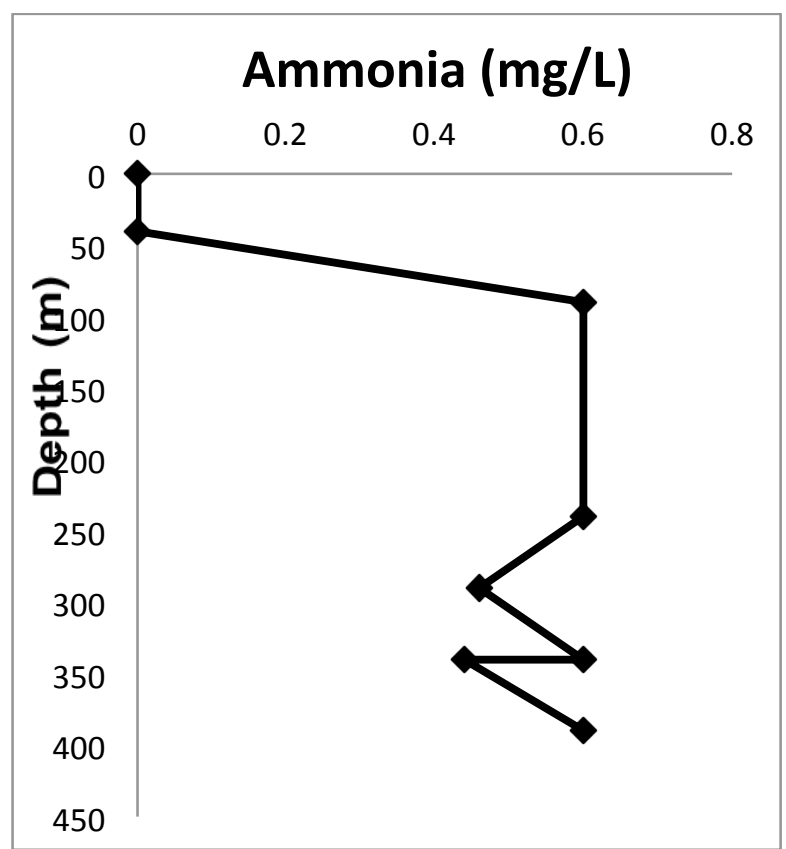

Figure5. The concentration of ammonia with depth

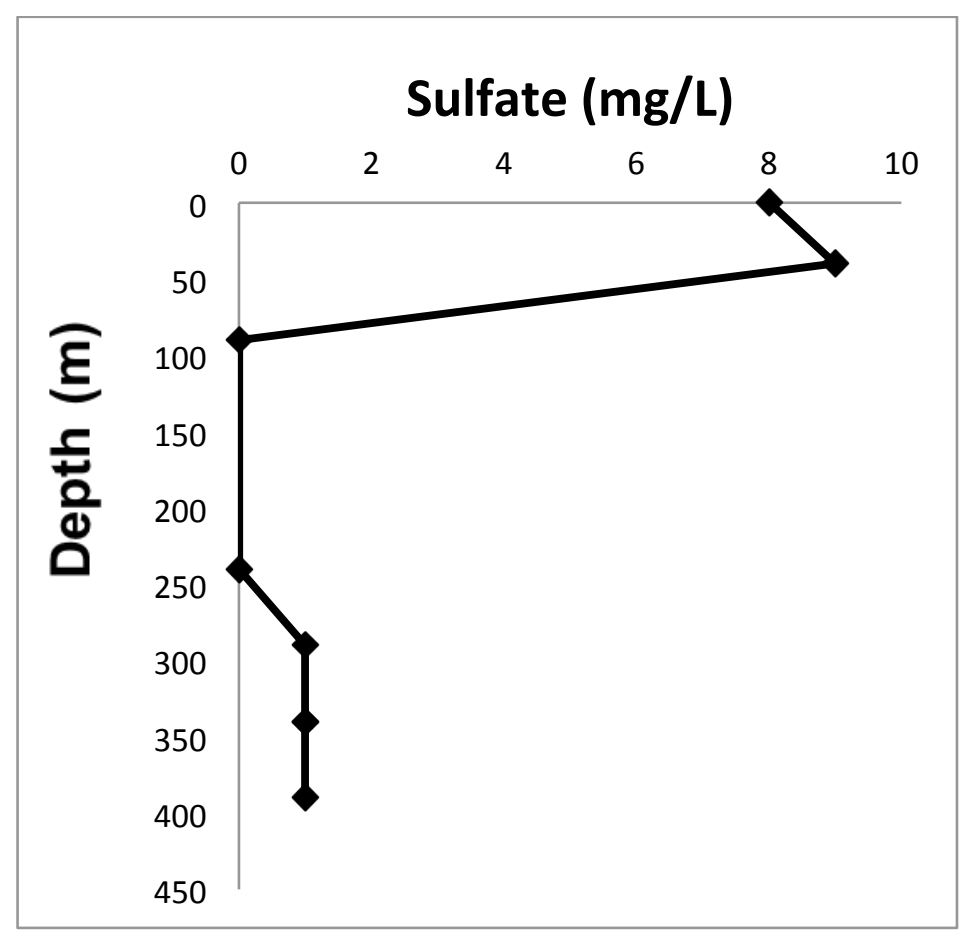

fig 6. The concentration of sulfate with depth 


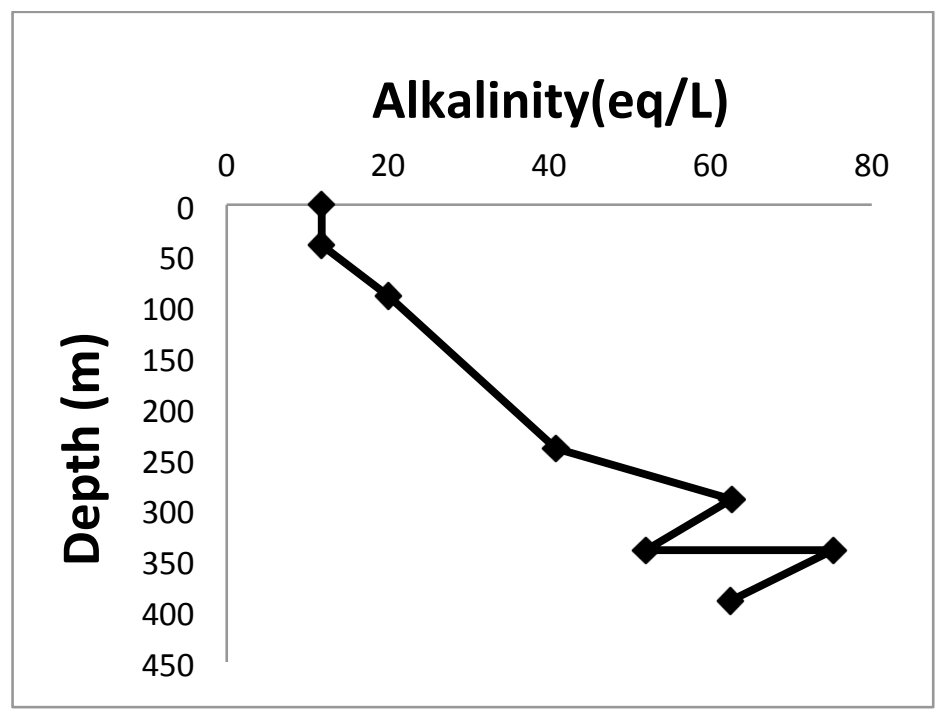

Fig7. The change of alkalinity with depthsfrom figure7, the two samples closest to the surface consist of both carbonate (only a little) and bicarbonate alkalinity and deeper samples are all bicarbonate alkalinity

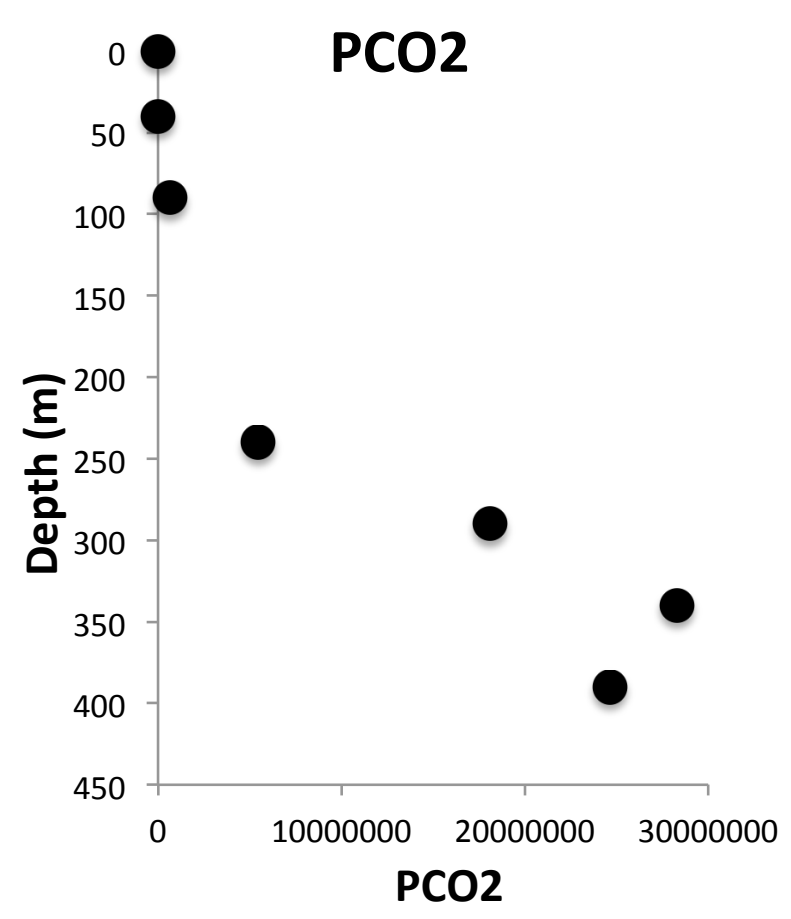

Figure 8.The partial pressure variation of Carbon dioxide with depth 


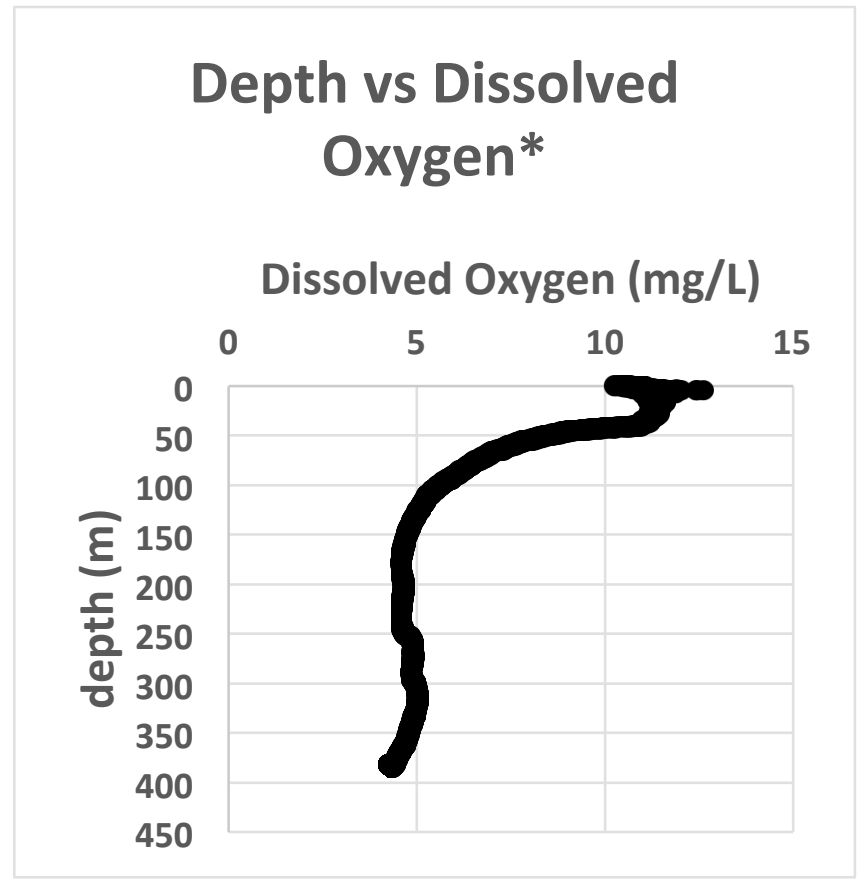

Figure 9.Dissolved oxygen with depth 


\section{Depth vs Conductivity}

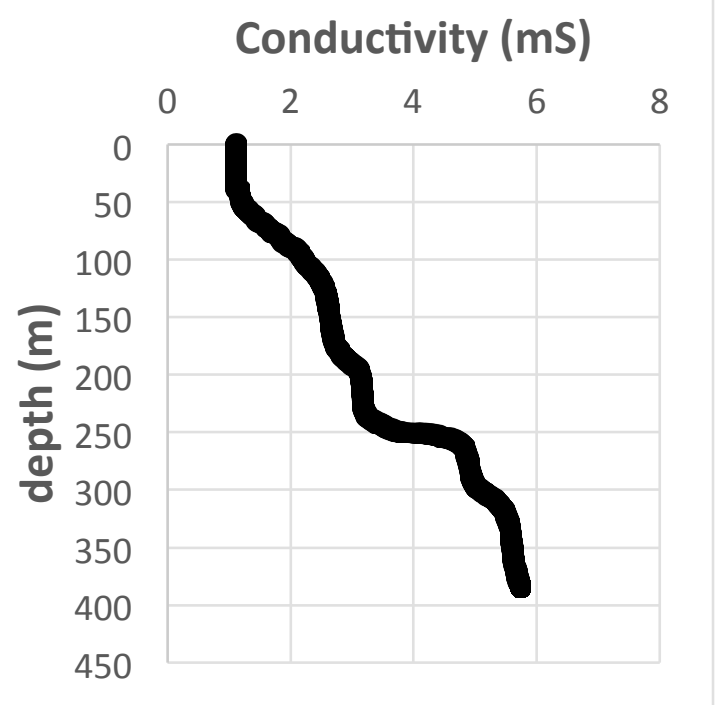

Figure 10. Conductivity with depth

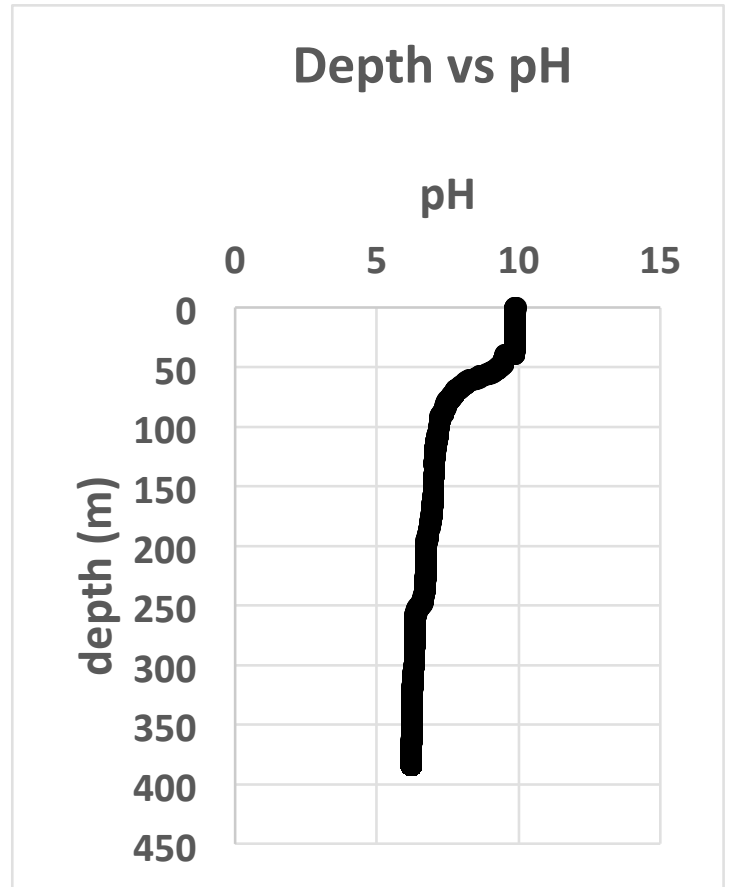

Figure 11.Variation of PH with depth 


\section{Discussion}

Water chemistry varies significantly along the depth profile. Lake Kivu exhibits a unique vertical density stratification that is driven by dissolved gasses (Schmidt \&Wuest, 2012) and the influx of saline groundwater. Except for anaerobic microbial processes, biologic activity only occurs in the mixoliminion (upper 60-65 m of the lake) (Schmidt \&Wuest, 2012).

Higher concentration $(9.2 \mathrm{mg} / \mathrm{l})$ of silica observed closer to the shoreline is likely a result of an influx of sediment derived from weathered bedrock (Figure 15), particularly near the outlets of streams and rivers. The increased concentrations of silica in the deeper water than surface waters are a result of the dissolution of diatoms below the photic zoneand the precipitation of calcite after being dissolved in water. The amounts of dissolved oxygen at the surface during the day are likely a result of photosynthetic processes (Figure 9). The conductivity infers to the salinity of the water,it is increasing downward due to the increased salts as a result of inflows of saline groundwater (Figure 10).Alkalinity increases in the monimolimnionlikely due to the precipitation of calcium carbonate in the upper levels of the water column and dissolution in the mixolimnion(fFigure 7) and saline groundwater is also likely alkaline. The concentration of phosphorus generally increases with depth as shown on figure 1 due to the deposition of phytoplankton in deep waters. In figure 3, Iron exhibits a decrease in concentrations at about 100-meter-deep with increasing age of deep waters. In the intermediate zone, the concentration increases due to the remineralization of iron. After, iron is removed to the sediments and unable tomixe back in the water leading to continuous depletion. Ammonia gets into water as runoff in farm landsdue to fertilizers usage this could be the main reason for increasing it in the lake water (figure 5).Partial Pressure of $\mathrm{CO}_{2}$ was calculated from Alkalinity, however, its accuracy is difficult to assess at this time. Calculation of $\mathrm{CO}_{2}$ flux suggests that $\mathrm{CO}_{2}$ moves upwards in the water column except in the deepest measurements where $\mathrm{CO}_{2}$ is transported down from $340 \mathrm{~m}$ to $390 \mathrm{~m}$, this process is unlikely (Figure 8).

There exists the variation with the data taken in June, 2018 and those taken in February, 2004 by Schmidt. Generally, the change is significant at greater depth. 


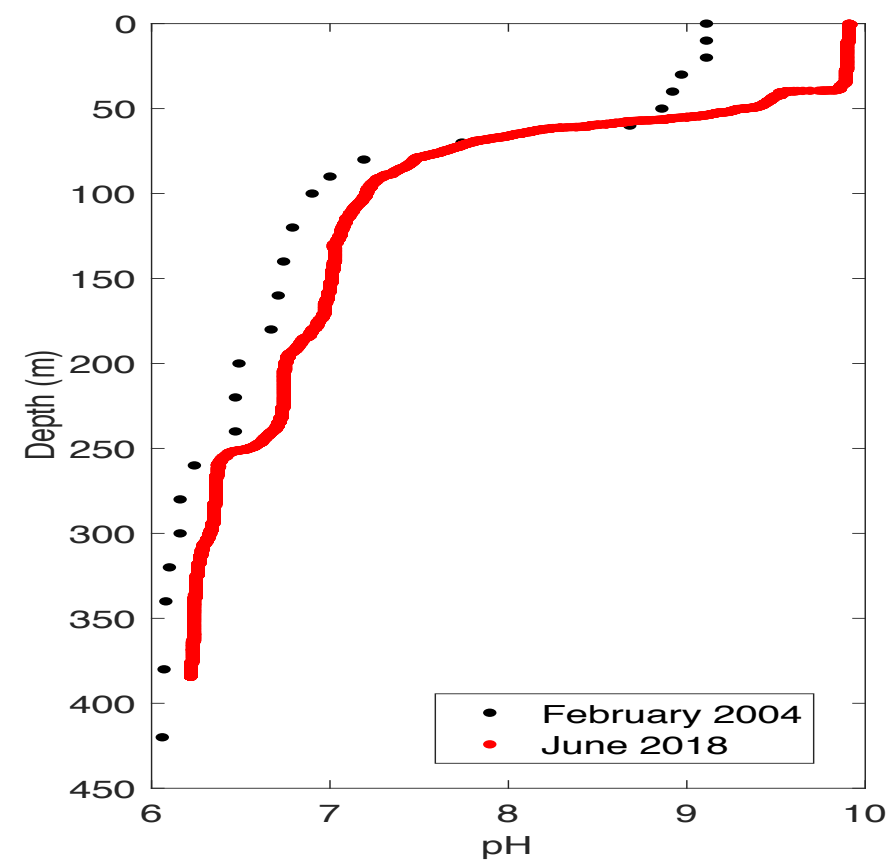

Fig 12. PH produced in february2004 and June2018

The increased temperature or excess nutrients from farmland runoff and waste water streams influence the growth higher algal and plant growth which result in the increase of $\mathrm{pH}$ level of lake water. Downward, the $\mathrm{pH}$ decreases with increase in temperature and the presence of carbon dioxide causes the acidity increase leading to the decrease in $\mathrm{pH}$ 


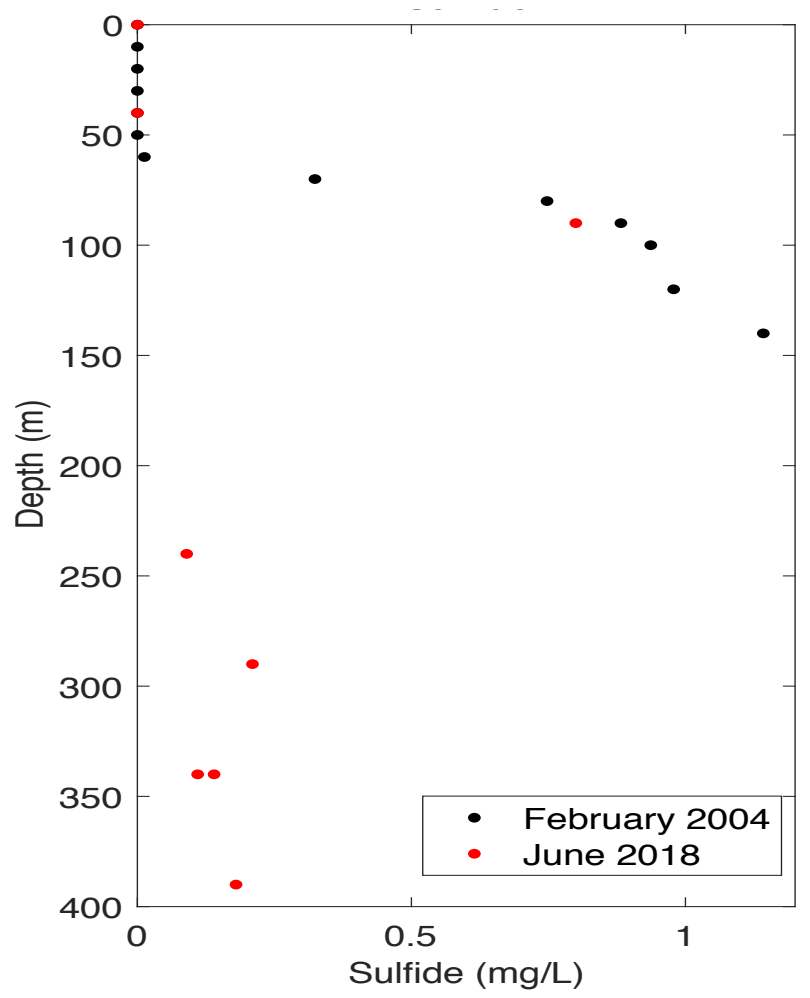

Fig 13.Sulfide concentrations(2004\&2018)

The sulfide concentration infers to the decrease of phytoplanktons, temperature increase (Kotch \& Erskine, 2001), increased sediment organic matter (Govers, et al., 2014), iron poor sediments( Marba et al., 2008 and deeper water with low oxygen content. From 2004 to 2018, the concentaration of sulfide decreased caused by the decrease in sedimentation rate of organic matter due to control measures taken. 


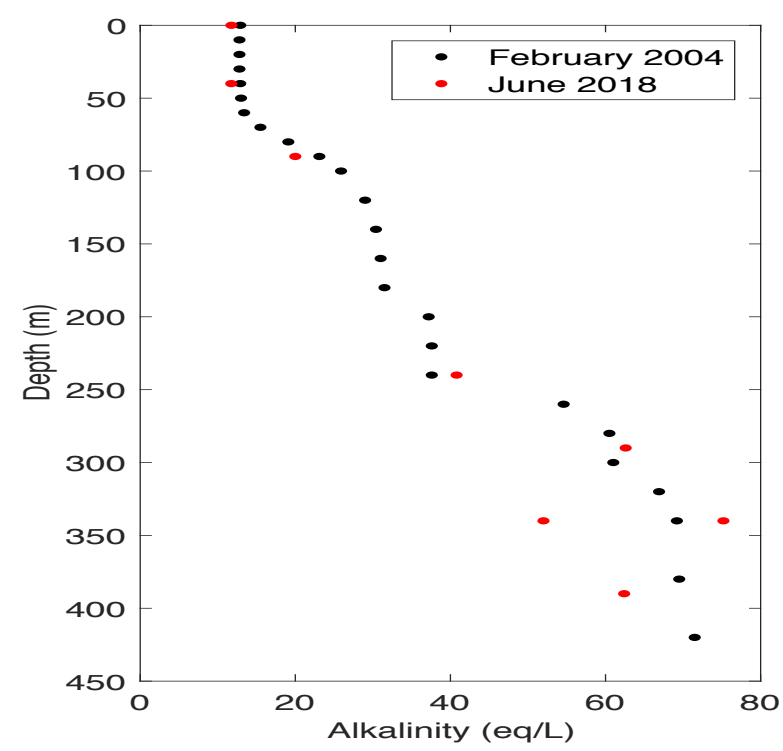

Figure 14. comparison of alkalinities

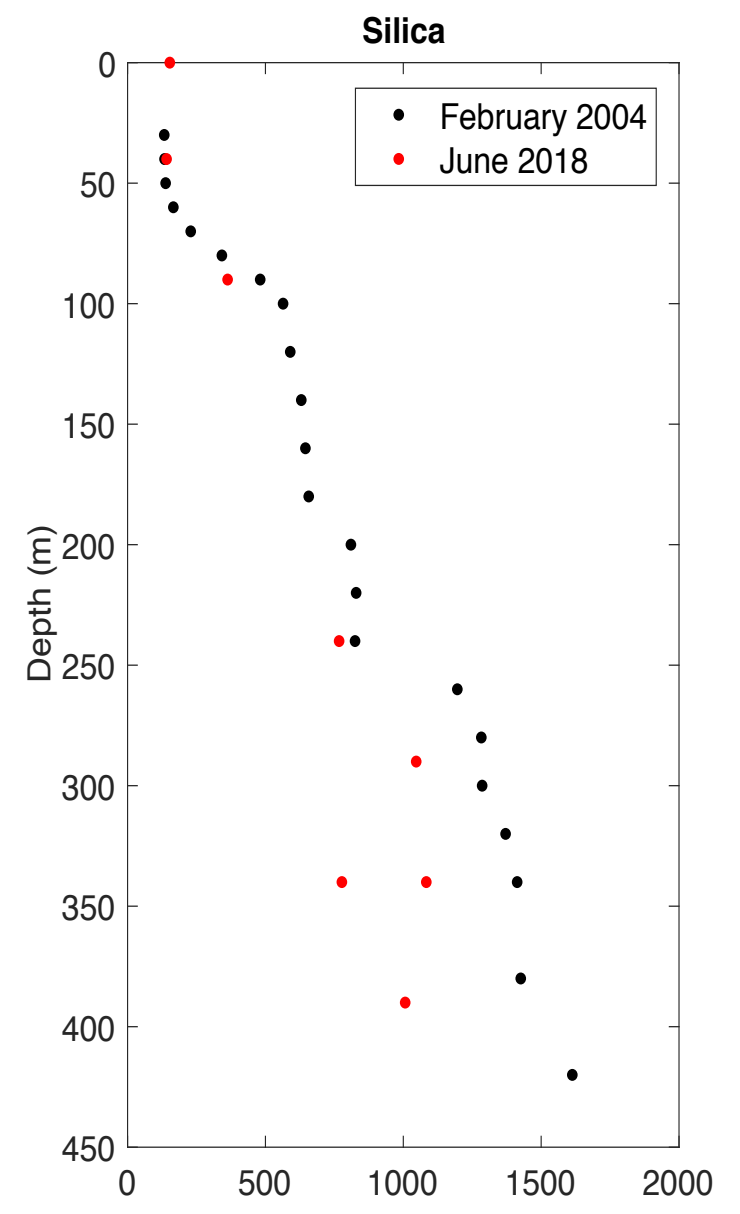


Figure 15. Comparison of silca content

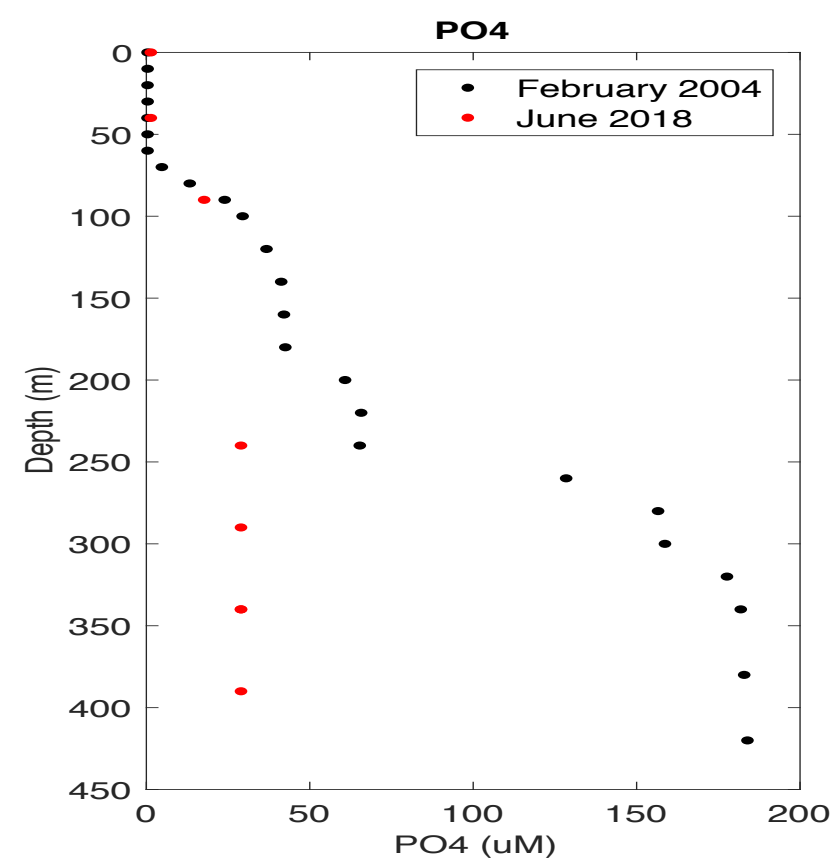

Figure 16. comparison of phosphate concentration

The concentration of phosphate is decreasing overtime (figure 16). This is due to the controlled runoff, prevention livestock from entering water sources, and manure management plan.

When ahuge volume of waste water from the residence and hospitals aredirectly dischargedinto the lake, it contributes chemicals to the chemical concentration of lake water body like phosphate and nitrates. Not only this but also agricultural runoff increase phosphate concentration in water from due to the use of fertilizers. Phosphate stimulates the productivity of plankton and aquatic plants which provide food for larger organisms, including zooplankton, fish, humans, and other mammals (Ricklefs \& Schluter, 1993). The decrease in phosphate concentration overtime will have a great effect on the aquatic life that feed on the zooplankton and phytoplankton. Anytime later, some organisms will disappear. 


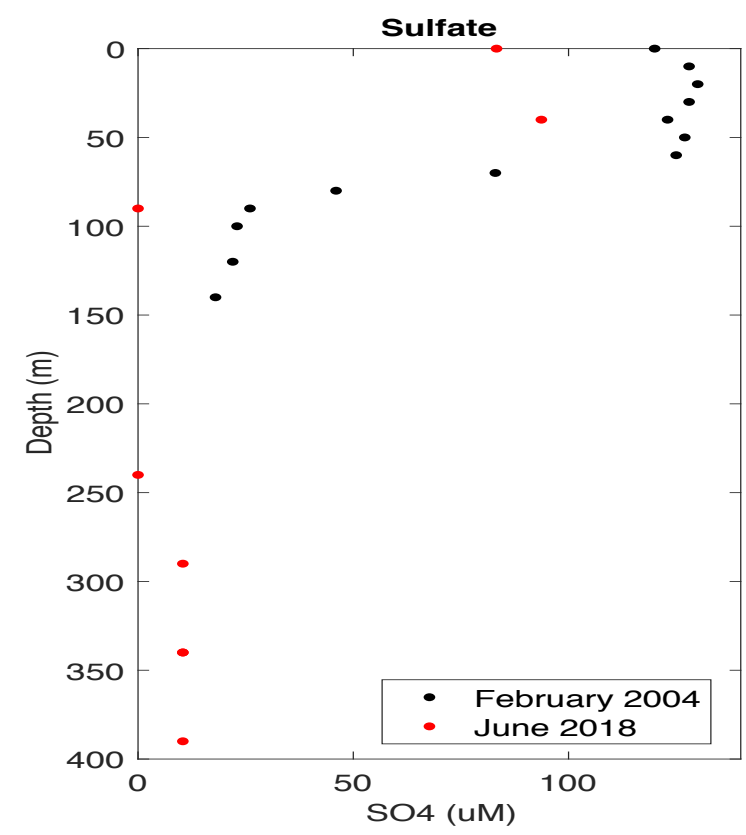

Figure 17. Comparison of sulfate concentrations

\section{5. conclusion}

Water chemistry varies significantly across different depths in Lake Kivu,the boundary between the mixolimnion and monolimnion was identified at approximately 40 meters based on Temperature and $\mathrm{PH}$ data derived from the CTD.This is 20 meters closer to the surface than previous studies that were 60 meters. Increases in turbidity occur at key boundaries identified in the temperature and conductivity data. Wastewater from the residence, hospitals contribute some chemicals like nitrates, sulfates into Lake Kivu water. Additionally, farmlands through erosion and runoff increase the concetration of phosphates in the water. The rise of concentrations of chemicals stimulates the growth of planktons and other marine organisms that can lead to the eutrophication consuming the available oxygen affecting negatively the aquatic life. The water of the lake is permanently stratified just because of the high salinity in the bottom of water the Lake Kivu. 


\section{Acknowledgment}

we sincerely appreciate The University of Rwanda School of Mining and Geology in collaboration with Syracuse Univeristy who helped us in data acquisitionproviding us equipments

\section{References}

Degens, E. T., R. P. von Herzen, H.-K. Wong, W. G. Deuser, and H. W. Jannasch (1973), Lake Kivu: Structure, chemistry and biology of an East African Rift Lake, Geol. Rundsch., 62, 245 277.

Govers, R., Marco, R., Rachel, F., Wout, K., Johanna, L., Stefano, L., . . Marius, S. (2014). The messinian salinity crisis: past and future of a great challenge of marine sciences. Marine Geology, 25.

Kotch, M., \& Erskine, J. (2001). Sulfide as a phytotoxin to the tropical seagrass Thalassia testudinum: interactions with light, salinity and temperature. Elsevier.

Marbà, N., Diaz-Almela, E., Alvarez, E., Santiago, R., Holmer, M., Grau, T., Danovaro, R., Argyrou, M., Karakassis, Y., Duarte, C.M., in press. Benthic input rates predict seagrass (Posidoniaoceanica) fish farm-induced decline. Mar. Pollut. Bull, doi:10.1016/j .marpolbul.2008.03.022.

Pasche, N., Schmid, M., Vazquez, F., Schubert, C. J., Wuest€ , A., Kessler, J. D., Pack, M.A., Reeburgh, W.S. \& Burgh- $€$ Mann, H. (2011) Methane sources and sinks in Lake Kivu. J. Geophys. Res.: Biogeosciences (2005-2012), 116(G3).

Pasche, N., G. Alunga, K. Mills, F. Muvundja, D. Ryves, M. Schurter, B. Wehrli, and M. Schmid (2010), Abrupt onset of carbonate deposition in Lake Kivu during the 1960s: Response to recent environmental changes, J. Paleolimnol., 44(4), 931-946, doi:10.1007/s10933-010- 9465-x.

Pasche, N., C. Dinkel, B. Müller, M. Schmid, A. Wüest, and B. Wehrli (2009), Physical and biogeochemical limits to internal nutrient loading of meromictic Lake Kivu, Limnol.Oceanogr., 54, 1863-1873, doi:10.4319/lo.2009.54.6.1863. 
Ricklefs, R., \& Schluter, D. (1993). Species diversity in ecological communities: historically and geographically perspectives. NMA, 416 .

Rwabuhungu R. Digne Edmond, (2011), Specific transverse distribution of nutrients and its majorimpact on sustainable development of the Lake Kivu methane gas exploitation, In :Mwakali J. Aand Alinaitwe H.M (Eds) Faculty of Technology, MakerereUniversity,Uganda, 551-557, ISBN 978-9970-214-00-7.

Selley,.R.C.(1998),Elements of Petroleum Geology, Second Edition.

Schmid, M., M. Halbwachs, B. Wehrli, and A. Wüest (2005), Weak mixing in Lake Kivu: New insights indicate increasing risk of uncontrolled gas eruption, Geochem. Geophys.Geosyst., 6, Q07009, doi:10.1029/2004GC000892.

Schmid, M., Ross, K., Wüest, A., 2012. Comment on "An additional challenge of Lake Kivu in Central Africa Upward Movement of the Chemoclines” by Finn Hirslund. J. Limnol. 71, e35.

Schmid, M., Wüest, A., 2012. Stratification, mixing and transport processes in Lake Kivu. In: Lake Kivu. Springer, pp. 13e29 (Netherlands).

Schmid, M., K. Tietze, M. Halbwachs, A. Lorke, D. McGinnis, and A. Wüest (2004), How hazardous is the gas accumulation in Lake Kivu? Arguments for a risk assessment in light of the Nyiragongo Volcano eruption of 2002, ActaVulcanol., 14/15, 115-121.

Schmid, M., M. Halbwachs, B. Wehrli, and A. Wüest (2005), Weak mixing in Lake Kivu: New insights indicate increasing risk of uncontrolled gas eruption, Geochem. Geophys.Geosyst., 6, Q07009, doi:10.1029/2004GC000892.

Schmid M, Ross K, Wüest A (2012) Comment on an additional challenge of Lake Kivu in Central Africa-upward movement of the chemoclines by Finn Hirslund. J Limnol 71(2):330-334.

Schmitz, D. M., and J. Kufferath (1955), Proble'mespose'es par la Pre'sence de GazdissousdanslesEauxprofondes du Lac Kivu, Acad. R. Sci. Colon. Bull. Se'ances, 1, 326 356. 
Tietze, K., M. Geyh, H. Müller, L. Schröder, W. Stahl, and H. Wehner (1980), The genesis of methane in Lake Kivu (central Africa), Geol. Rundsch., 69, 452-472, doSi:10.1007/BF02104549.

Tietze, K., 2000. Lake Kivu Gas Development and Promotion-related Issues: Safe and Environmentally Sound Exploration. Republic of Rwanda, Ministry of Energy, Water and Natural Resources, Unit for the Promotion and Exploitation of Lake Kivu Gas, Kigali, p. 110. PDT report no. 520002.

Tietze, K., Geyh, M., Müller, H., Schröder, L., Stahl, W., and Wehner, H., 1980, The genesis of the methane in Lake Kivu (Central Africa): GeologischeRundschau, v. 69, n. 2, pp. 452-472 